\title{
ANÁLISE CLIMÁTICA E A DISTRIBUIÇÃo DOS CASOS DE DENGUE EM FORTALEZA
}

\author{
Juliana Rodrigues Alves ${ }^{(a)}$, Antonio Ferreira Lima Júnior ${ }^{(b)}$, Jéssica Freitas e Silva ${ }^{(c)}$ Maria \\ Elisa Zanella ${ }^{(\mathrm{d})}$
}

(a) Geografia, Universidade Federal do Ceará, julianageografiaufc@gmail.com

(b) Geografia, Universidade Federal do Ceará, junioegeoufc@ gmail.com

(c) Geografia, Universidade Federal do Ceará, jessica.ufc @ hotmail.com

(d) Geografia, Universidade Federal do Ceará, elisazv@ @erra.com.br

\section{Eixo: Climatologia em Diferentes Níveis Escalares: Mudanças e Variabilidade}

\begin{abstract}
Resumo/
A dengue é uma doença viral, transmitida pelo mosquito Aedes aegypti, ela acontece principalmente nas regiões tropicais do globo, por apresentarem condições favoráveis à proliferação do mosquito vetor da doença. Fortaleza é o município do Ceará em que mais se concentra o número de casos da doença, por apresentar conjunturas ambientais caracterizadas por clima com elevadas temperaturas e período chuvoso concentrado na quadra chuvosa. A obtenção dos dados para análise se deu através do Sistema de Monitoramento Diário de Agravos (SIMDA), para dados da doença, e Instituto Nacional de Meteorologia (INMET) para dados climatológicos. A compreensão e análise da relação desses dados da doença e dos fatores climáticos (temperatura, umidade relativa do ar, pressão atmosférica, velocidade e direção dos ventos, precipitação) foram feitos através do método da análise rítmica, desenvolveu-se gráficos para tais resultados. Sendo possível observar a influência de elementos climáticos na propagação da doença.
\end{abstract}

Palavras chave: Dengue, Fortaleza, Analise Rítmica.

\section{Introdução}

A dengue é uma doença viral, sendo transmitida pelo mosquito Aedes aegypti cujos sintomas são febre alta, dor de cabeça, dores no corpo e articulações, prostração, fraqueza, dor atrás dos olhos, erupção e coceira na pele. Sua ocorrência se dá principalmente nos países tropicais, devido às condições ambientais e sociais favorecerem a proliferação do mosquito vetor da doença.

A incidência da dengue no estado do Ceará, segundo Magalhães (2010) se deu a partir da introdução do vírus em 1986. Na capital do Estado, Fortaleza, é onde se concentra o maior numero de casos da doença, e onde há um maior investimento por parte do Governo no combate a mesma.

Fortaleza se encontra no litoral leste do estado e sua caracterização climática está relacionada a elevadas temperaturas ao longo do ano e a chuva concentrada no que chamamos de quadra chuvosa (estação chuvosa), que vai de fevereiro a maio, correspondendo ao período de atuação da Zona de Convergência 
Inter Tropical (ZCIT) no estado. Outros sistemas causadores de chuva são os Vórtices Ciclônicos de Altos Níveis (VCANs) que atuam na pré-estação chuvosa, nos meses de dezembro e janeiro, na pós-estação chuvosa observa-se a atuação das Ondas de Leste (OL).

\section{Metodologia}

A compreensão das relações pré-estabelecidas entre os elementos climáticos e a saúde humana é parte fundamental deste trabalho. O clima funciona como condicionante para a proliferação de várias doenças, por intermédio de diferentes vetores (ROUQUAYROL, 1993), sendo de extrema importância o aprofundamento do conhecimento climático global, regional e local para que, em associação a ele e ao processo de urbanização e das políticas públicas, tratar da problemática da dengue nos dias atuais e em respectivas configurações futuras.

A metodologia utilizada foi à análise rítmica (Figura 1, 2, 3, 4), conforme proposta por Monteiro (1971), onde a correlação diária entre os tipos de tempo e a variação dos elementos climáticos proporciona associar a gênese do tempo e do clima ao seu impacto na natureza e na sociedade, tal como situações de tempo favoráveis à proliferação de doenças, como a dengue.

Os dados da dengue do período de julho de 2014 a junho de 2015 foram coletados por meio do site do Sistema de Monitoramento Diário de Agravos (SIMDA), que são disponibilizados pelo governo do estado do Ceará. Os dados climáticos foram obtidos através do site do Instituto Nacional de Meteorologia (INMET), e as imagens de satélite e cartas sinóticas foram obtidas através do Centro de Previsão de Tempo e Estudos Climáticos (CPTEC) e Marinha do Brasil, respectivamente, para identificar os sistemas atmosféricos atuantes do município.

\section{Resultados e Discussão}

Através dos valores de temperatura máxima, média e mínima, umidade relativa do ar, pressão atmosférica, velocidade e direção dos ventos e precipitação foi possível a construção de um gráfico de análise rítmica, onde foi inserido também os casos de dengue para o município no período analisado.

Destacam-se dois períodos climáticos importantes para o município de Fortaleza, o período seco (segundo semestre) e período chuvoso (primeiro semestre). É possível notar também, que os casos de dengue seguem uma regularidade em relação a cada período climático, onde os picos de casos ocorrem concomitantes ao primeiro semestre do ano, como é perceptível na analise rítmica (Figura 3,4).

Através da análise sinótica foi possível identificar os sistemas atmosféricos atuantes do município durante o período analisado. Foram estes a Massa Equatorial Atlântica $(\mathrm{mEa})$, massa de ar quente e com vorticidade anticiclônica responsável pela estabilidade atmosférica na região, atua durante todo o ano. A 


$\begin{array}{lc}\begin{array}{l}\text { XVII Simpósio Brasileiro } \\ \text { de Geografia Fisica Aplicada }\end{array} & \text { OS DESAFIOS DA GEOGRAFIA FÍSICA NA FRONTEIRA DO CONHECIMENTO } \\ \begin{array}{l}\text { I Congresso Nacional } \\ \text { de Geografia Física }\end{array} & \begin{array}{c}\text { Campinas - SP } \\ \text { Instituto de Geociências - Unicamp }\end{array} \\ \text { Camo Junho à } 02 \text { de Julho de } 2017\end{array}$

estabilidade atmosférica é interrompida pela atuação dos sistemas causadores de chuva, destacando a ZCIT e secundariamente os VCAN e OL.

Em relação aos elementos do clima e a doença, pode-se notar relação com a precipitação, onde os meses de fevereiro, março e abril, antecedem os meses com maiores registros da doença, sendo estes os meses de maio e junho, tendo também abril casos importantes. Sendo assim, entendemos que a precipitação concentrada e um período de diminuição desta, propiciam condições adequadas para a proliferação do mosquito e em consequência registros de casos da doença.

\section{Considerações Finais}

O município de Fortaleza está localizado em zona climática equatorial, o que propicia condições ideais para a proliferação do mosquito, vetor da dengue. Por tanto, há necessidade de compreender o comportamento dos elementos naturais (climáticos) que podem interferir na distribuição temporal da doença. Sendo assim, as altas temperaturas, a umidade relativa constantemente elevada e o vento contribuem para que a concentração dos casos de dengue se deem no primeiro semestre do ano, onde também consiste o período chuvoso para a região. As chuvas concentradas, com períodos de estabilidade para tempo contribuem para que a doença concentre o maior número de casos entre os meses de abril a junho.

\section{Figuras e Tabelas}

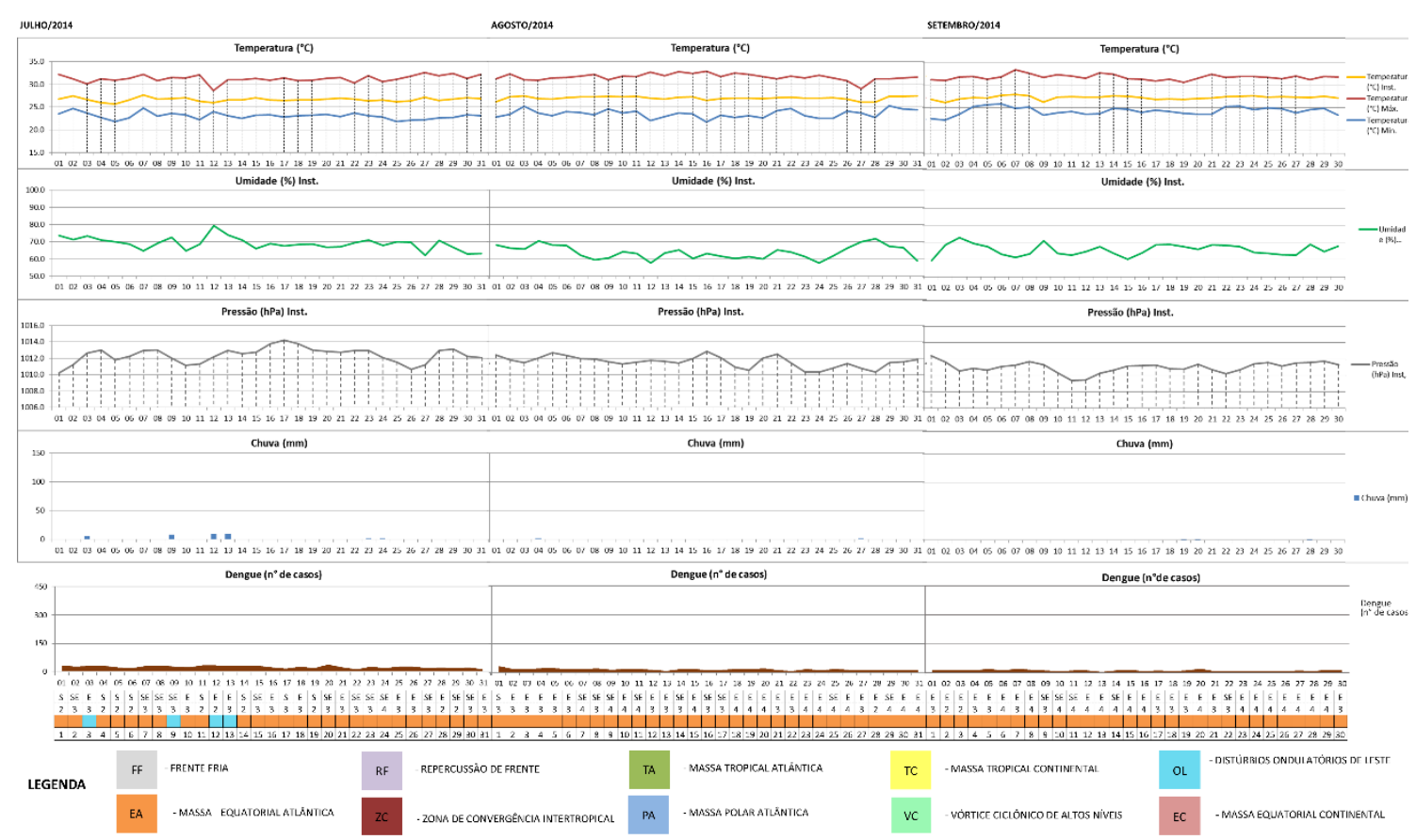




$\begin{aligned} & \text { XVII Simpósio Brasileiro } \\ & \text { de Geografia Fisica Aplicada }\end{aligned}$
$\begin{aligned} & \text { I Congresso Nacional } \\ & \text { de Geografia Física }\end{aligned}$

Figura 1 - Análise Rítmica de julho a setembro de 2014

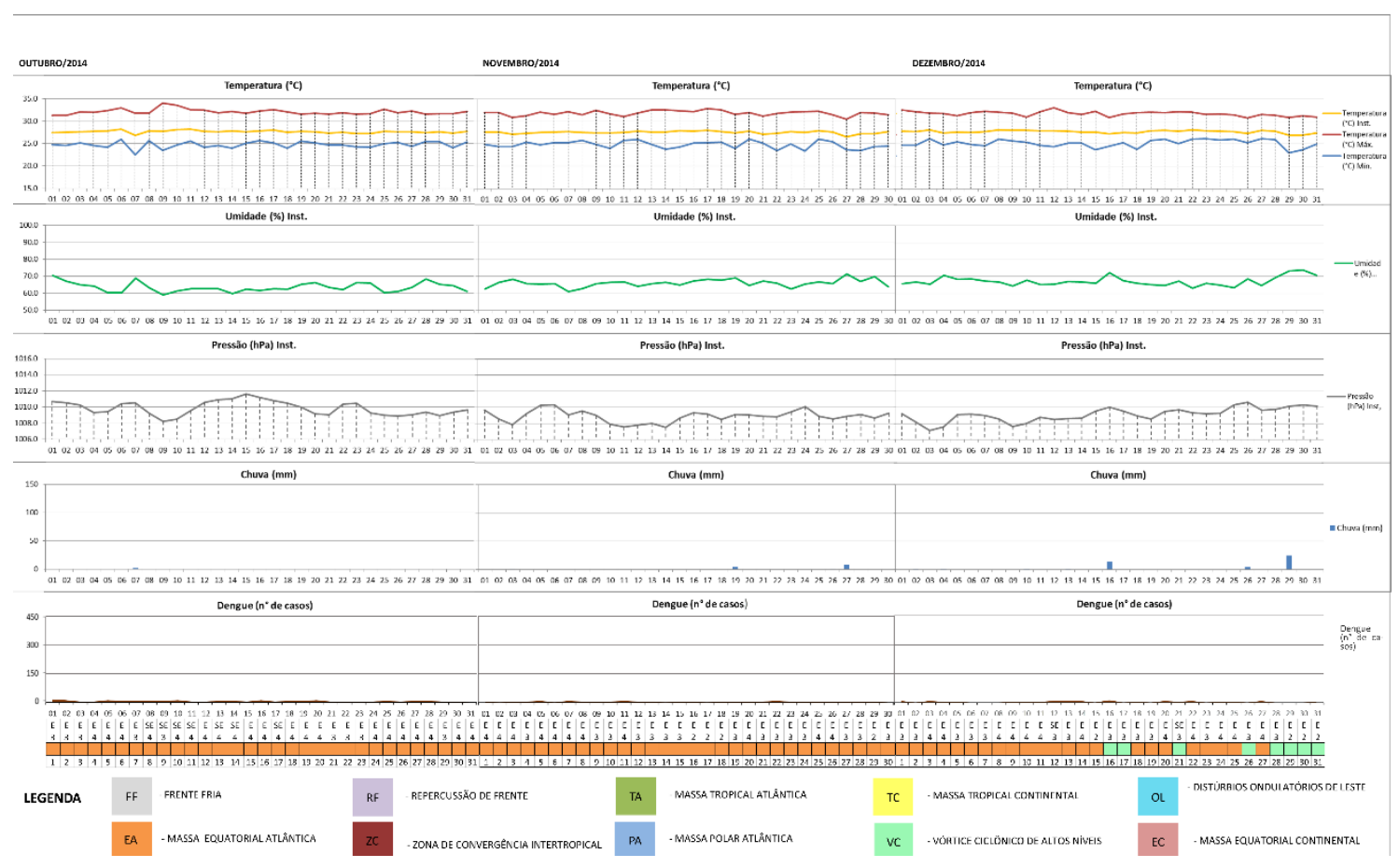

Figura 2 - Análise Rítmica de outubro a dezembro de 2014



Figura 2 - Análise Rítmica de janeiro a março de 2015 

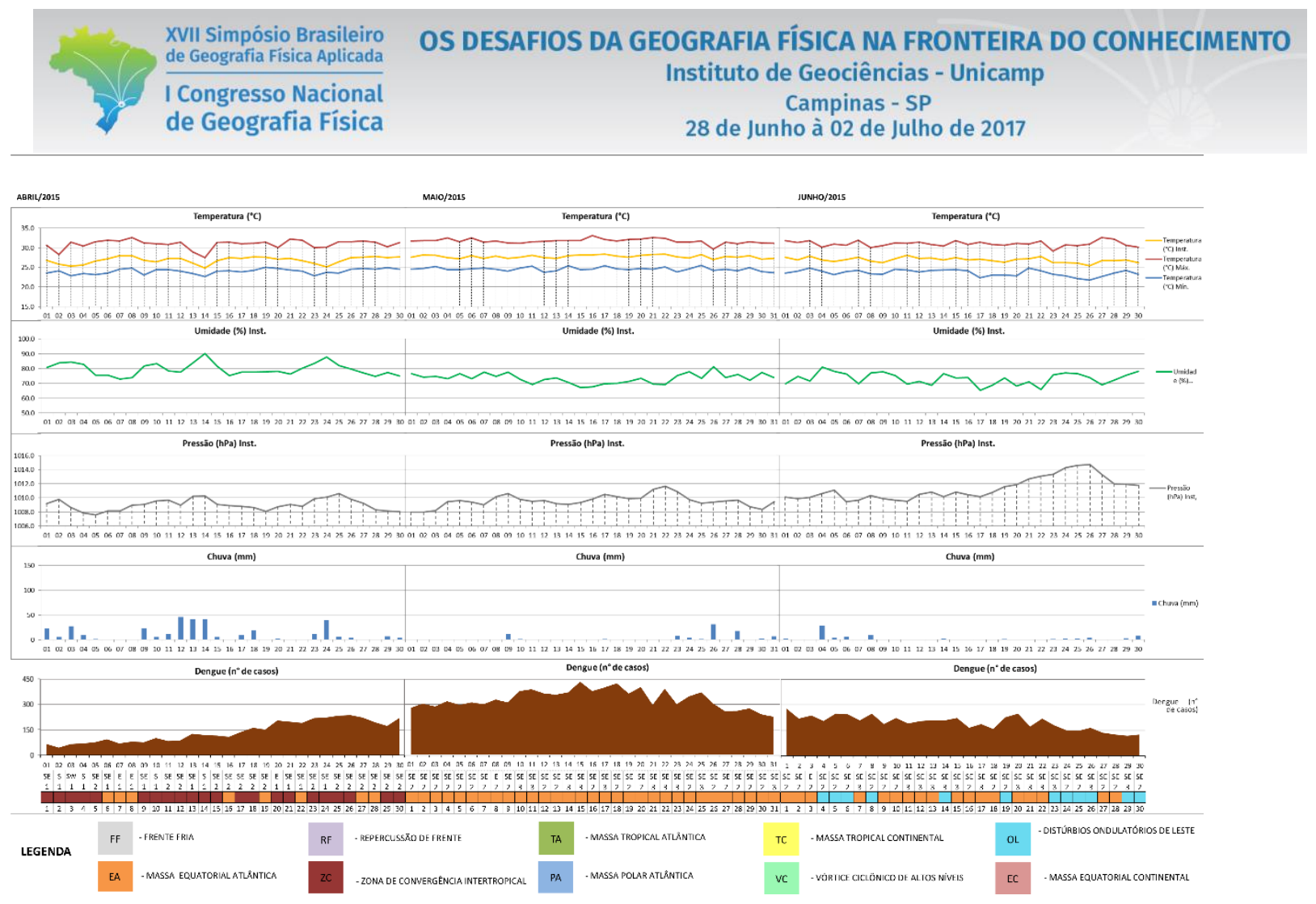

Figura 2 - Análise Rítmica de abril a junho de 2015

\section{Bibliografia}

MAGALHÃES, Gledson Bezerra. Http://www.cchla.ufrn.br/seminariogovernanca/cdrom/ST6_Gledson.pdf. Disponível em: <http://www.cchla.ufrn.br/seminariogovernanca/cdrom/ST6_Gledson.pdf >. Acesso em: 06 mar. 2017.

MONTEIRO, C. A. F. Análise rítmica em Climatologia. Problemas da atualidade climática no Estado de São Paulo e achegas para um programa de trabalho. São Paulo: Instituto de Geografia da Universidade de São Paulo, 1971. (Série climatologia 1).

ROUQUAYROL, M. Z. et al. Epidemiologia \& Saúde. 4ed. Rio de Janeiro: MEDSI,1993,527p. 